\title{
The Relationship between Board Characteristics and Earnings Management: Evidence from Sri Lankan Listed Companies
}

\author{
C. A. Kankanamage \\ South Asían Institute Of Technology and Medicine, Sri Lanka \\ chinthakaamila82@gmail.com
}

\begin{abstract}
This paper aims to examine the impact of board characteristics on earnings management in Sri Lanka during the period from 2012-2015. The current study uses the ordinary least squares regression (OLS) to examine the effect of board on earnings management for a sample of 160 listed firms in Sri Lanka from 2012-2015. Kothari, Lenon and Wesley (2005) performance adjusted discretionary accrual model used to measure the earnings management by using the discretionary accruals. Findings revealed that there is a significant relationship between board size, board composition, board financial expertise and board meetings and earnings management of the firms. Thus effective board of a firm is contributing to enhance the financial reporting quality and transparency. The findings of this study would provide useful information for regulators and the practioners in the country to understand the significance of board characteristics of firms to constrain the earnings management and enhance the financial reporting quality and transparency. Further results provide useful information to the investors and other stakeholders in evaluating the existence of effective board characteristics in advance to put the confidence of the financial reporting quality and make their decisions.
\end{abstract}

Keywords: Board Characteristics, Corporate Governance, Earning Management, Financial Reporting Quality

\section{Introduction}

Corporate governance (CG) is an emerging field all around the world and it sees how governance practices of the organization happened to the best interest of stakeholders in a firm.CG mechanism seeks to accomplish the interests of all the stakeholders' without giving prominence to any stakeholder. Due to the separation of ownership and control, shareholder involvement for the firm is less and managers are empowered to act on behalf of the shareholders. Through this delegation process, managers are getting a higher authority and control to run the business and make managerial decisions. But the expectations of the managers and the shareholders cannot be perfectly aligned with each other. This creates an agency conflict among them in a business. In such circumstances earning management is used by the managers to use their professional judgment in financial reporting to materially misstate the financial statement numbers to accomplish their self interest objectives.

Issue of earnings management have been receiving a higher attention and focus concern from government, accounting professional bodies as well as the public, particularly after the high profile corporate governance scandals such as Enron, WorldCom, Satyam Computers, Pelmet which were occur throughout the world. Most of these CG scandals termed as major accounting scandals because underlying cause 
for the failure was materially misstate the financial statements to mask the true financial information of the firm by using EM practices due to lack of corporate governance specially a weaker board in the firms. Therefore Sarbanes Oxley Act in 2002 emphasized the significance of a strong board to constrain the earnings management in firms. Those board characteristics are board size, board composition, board financial expertise and the board meetings. There are mix findings of the previous empirical findings on the contribution board characteristics to constrain the EM. This paper is investigating the relationship between the board characteristics and earnings management in Sri Lankan context.

\section{Literature Review}

In general when the size of the board is increasing it is expected to reduce the discretionary accruals and improve the financial reporting quality due to the higher degree of inspection and monitoring by the board of directors. Fama and Jensen (1983) describe the board of directors as the most important mechanism in the internal corporate governance structure of any firm. From an agency perspective, larger boards are more likely to be vigilant for agency problems because substantial number of experienced directors can be deployed to monitor and review management actions (Kiel and Nicholson, 2002).The agency theory perspective also conceives that larger boards support effective monitoring by reducing CEO dominance within the board and they protect shareholders' interests (Singh \& Harianto, 1989). They pointed out that larger boards improve the bargaining position of the board with regard to the CEO and thus larger boards are more effective in monitoring the management.

Board independence is mainly related to the number of independent directors as explained in the agency theory. Park and Shin (2004) examined the effect of board composition on earnings management and found that non executive directors help to restrain earnings management and have the lower level of abnormal accruals. Dechow, Sloan, and Sweeney (1996) found that firms with a large percentage of nonexecutive members are less likely to be subject to accounting enforcement actions for alleged GAAP violations. Roodposhti and Chashmi (2011) did a study for the period of 2004 to 2008 in Iran using 196 firms listed on Tehran Stock Exchange and revealed a negative association between board independence and earnings management.

The accounting and financial knowledge are beneficial to board of directors to understand better financial statements and financial reporting issues. By having such background directors are capable of identifying the financial statement misstatements more and managers are reluctant to adjust the financial information for their self interest.Cadbury report (1992) states that the financial competence of non-executive board members is of special importance for the effectiveness of the board and the results of many studies support this statement. Carcello and Neal (2002) suggested that the boards of directors' members who have more financial experiences and the 
background more likely to constrain the opportunistic choices of managers. Further, Chtourou (2001) claimed that when the directors with a higher tenure of financial experience are there in the firm managers are less likely to be associated with EM practices.

Frequency of the board meetings is having potential to improve the quality of earnings due to the continuous inspection and the supervision of the financial statements by the board of directors of the firms. There are number of empirical findings that can be found in the literature supporting to this argument. One of the responsibilities of the director is attending meeting and by doing so they would have the privilege to monitor the actions of the managers more deeply (Ronen \&Yaari, 2008). One essential measure of the effectiveness of a board is how often the board members meet to discuss the various issues facing by a firm (Vafeas, 1999). Diligent boards enhance the level of oversight, resulting in improved financial reporting quality. Carcello and Neal (2002) found that quality of financial reporting is closely associated with the number of board meetings.

\section{Conceptual Framework}

\section{Independent Variables}

- Board size

- Board composition

- Board financial expertise

- Board meetings

Figure 01: Conceptual Framework

Source: Author

\section{Methodology}

\subsection{Population and Sample}

This study included all the listed companies in the Colombo Stock Exchange (CSE) during the period of 2011-2014.One Hundred and Sixty (160) CSE listed companies excluding companies in the banking, finance and insurance industry included in the sample. 


\subsection{Data Collection}

This study uses secondary data and such data were collect from the published financial statements in the annual reports of the companies listed in the listed company directory.

\subsection{Operationalization and Data Analysis}

\section{Table 01: Operationalization of Dependent and Independent Variables}

\begin{tabular}{|l|l|l|}
\hline \multicolumn{1}{|c|}{ Code } & \multicolumn{1}{|c|}{$\begin{array}{c}\text { Variable } \\
\text { Name }\end{array}$} & \multicolumn{1}{c|}{ Proxy } \\
\hline BSIZE & Board Size & $\begin{array}{l}\text { Total Number of directors serving on the board to participate in } \\
\text { the decision making of the firm. }\end{array}$ \\
\hline BCOMP & $\begin{array}{l}\text { Board } \\
\text { composition }\end{array}$ & $\begin{array}{l}\text { This is a dummy variable. } \\
\text { The Board should include at least two non-executive directors } \\
\text { or such number of non-executive director's equivalent to one } \\
\text { third of total number of directors, whichever is higher. If the } \\
\text { above requirement satisfy=1, Otherwise=0. }\end{array}$ \\
\hline BFEXP & $\begin{array}{l}\text { Board financial } \\
\text { Expertise }\end{array}$ & $\begin{array}{l}\text { This is a dummy variable. } \\
\text { If the board consists of majority of the directors who are } \\
\text { financial experts =1, otherwise=0. } \\
\text { Financial expertise of the board should include academic and } \\
\text { professional qualifications in finance and the at least 5 years of } \\
\text { experience dealing with the financial matters in the industry. }\end{array}$ \\
\hline BMEET & $\begin{array}{l}\text { Board } \\
\text { meetings }\end{array}$ & $\begin{array}{l}\text { Total number of meetings held with the representation of } \\
\text { majority of board of directors during a particular financial year. }\end{array}$ \\
\hline DA & $\begin{array}{l}\text { Discretionary } \\
\text { accruals }\end{array}$ & $\begin{array}{l}\text { This is the dependent variable of the study. } \\
\text { Absolute value of the discretionary accruals estimated by the } \\
\text { Kothari, Leone and Wesley (2005) model. } \\
\text { Absolute value of discretionary accruals is calculated by the } \\
\text { residuals represented by the error term of the ordinary least } \\
\text { square regression. }\end{array}$ \\
\hline
\end{tabular}

Kothari, Lenon and Wesley (2005) performance matched discretionary accrual model applied to detect the non discretionary accruals of the firms. Ordinary least regression (OLS) model used to test the relationship between the board characteristics and earnings management. 


\section{Formulae 1:}

$$
\frac{\mathrm{TA}_{\mathrm{i}, t}}{\mathrm{~A}_{\mathrm{i}, \mathrm{t}-1}}=\beta_{0}+\beta_{1}\left(\frac{1}{\mathrm{~A}_{\mathrm{i}, \mathrm{t}-1}}\right)+\beta_{2}\left(\frac{\Delta \operatorname{REV}_{\mathrm{i}, \mathrm{t}}-\Delta \mathrm{REC}_{\mathrm{i}, \mathrm{t}}}{\mathrm{A}_{\mathrm{i}, \mathrm{t}-1}}\right)+\beta_{\mathrm{a}}\left(\frac{\mathrm{PPE}_{\mathrm{i}, \mathrm{t}}}{\mathrm{A}_{\mathrm{i}, \mathrm{t}-1}}\right)+\beta_{4}\left(\mathrm{ROA}_{\mathrm{i}, \mathrm{t} \text { or } \mathrm{i}, \mathrm{t}-1}\right)+\varepsilon_{\mathrm{i}, \mathrm{t}}
$$

\section{Formulae 2:}

$\mathrm{TA}_{\mathrm{i}, \mathrm{t}}=\mathrm{NI}_{i, t}-C F \mathrm{O}_{i, t}$

\section{Formulae 3:}

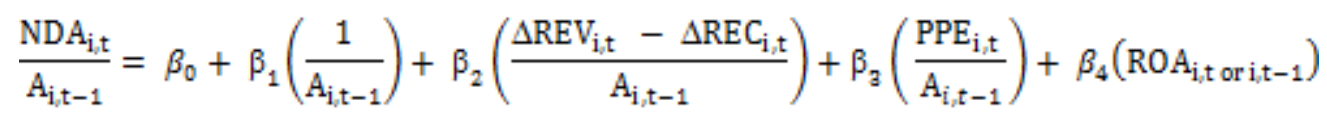

\section{Formulae 4:}

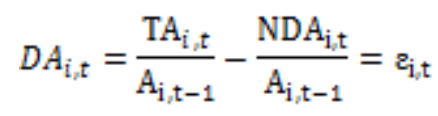

\section{Formulae 5:}

$D A_{\text {it }}=\beta_{0}+\beta_{1} B S I Z E+\beta_{2} B C O M P+\beta_{a} B F E M P+\beta_{4} B M E E T$

\section{Where:}

$T A_{\mathrm{i}, \mathrm{t}}=$ Total accruals of firm $\mathrm{i}$ in year $\mathrm{t}$

$N D A_{i, t}=$ Non-discretionary accruals of firm $\mathrm{i}$ in year $\mathrm{t}$

$A_{\mathrm{i}_{i} \mathrm{t}-1}=$ Total assets of firm $\mathrm{i}$ in year $\mathrm{t}-1$

$\triangle R E V_{\mathrm{i}_{\Perp} \mathrm{t}}=$ Change in revenue of firm $\mathrm{i}$ in year $\mathrm{t}$

$\triangle R E C_{\mathrm{i}_{\mathrm{i}} \mathrm{t}}=$ change in receivables of firm $\mathrm{I}$ in year $\mathrm{t}$

$P P E_{\mathrm{i}_{\mathrm{s}} \mathrm{t}}=$ Gross property, plant and equipment of firm $\mathrm{i}$ in year $\mathrm{t}$

$R O A_{\mathrm{i}_{\mathrm{i}} \mathrm{t}}=$ Return of assets of firm $\mathrm{i}$ in year $\mathrm{t}$

$T A_{\mathrm{i}, \mathrm{t}}=$ Total accruals of firm $\mathrm{i}$ in year $\mathrm{t}$

$D A_{\mathrm{i}, \mathrm{t}}=$ Discretionary accruals of firm $\mathrm{i}$ in year $\mathrm{t}$

$\varepsilon_{\mathrm{i}, \mathrm{t}}=$ Residuals of firm $\mathrm{i}$ in year $\mathrm{t}$

$\beta_{0,}, \beta_{1}, \beta_{2}, \beta_{a}, \beta_{4}=$ Firm specific parameters calculated by the OLS regression model

$\mathrm{NI}_{\text {it }}=$ Net profit after tax of firm $\mathrm{i}$ in year $\mathrm{t}$

$C F O_{\text {it }}=$ Cash flow from operation of firm $\mathrm{i}$ in year $\mathrm{t}$ 


\section{Findings and Discussions}

Table 02 represents the results of the descriptive statics and the correlation matrix. According to the results firms are having average size of eight directors in there boards while the average numbers of board meetings are six. That means board of directors re meeting at least twice per financial year to discuss about the matters in the firm. Board size is positively correlated with the board financial expertise and the board independence, while negatively correlated with the board meetings. Board financial expertise is positively correlated with the board meetings and the board composition. Also board meeting are negatively correlated with the board composition.

Before conducting the OLS regression preliminary analysis is conducted to ensure the assumptions of multivariate analysis such as normality, homoscedasticity, linearity and multicollinearity are tested. To test the normality, skewness index and kurtosis index are used (Kline, 2004). Variables follow a univariate normal distribution since the skewness index is less than 3 and kurtosis index is less than 10. Linearity also tested by using the scatter and residual plots. It was observed that all the scatter plots are scatter around zero and have an oval shape. Homoscedasticity tested by using the graphical approach. The residual plots drawn to observe linearity no funneling was observed which ensure that variances of their error terms are constant. Variance Inflation Factor (VIF) and tolerance statistics are used to test multicollinearity. Generally accepted threshold level of VIF is 10 (O'Brien, 2007) and the tolerance value should be closer to 1 (Field, 2009). For all the variables of this paper VIF is less than 10 and the tolerance level is less than 1. After ensuring the assumptions of the multivariate analysis following findings were observe in the OLS regression analysis.

Table 3 represents the OLS regression results of the study. According to the results all the board characteristics significantly affect to the earnings management of the firms. Board size is having a significant positive relationship while board financial expertise, board independence and board meetings are having a significant negative relationship to the earnings management of the firms. This is consistent with the previous empirical findings of the Beasley (1996), Chang (1999), Dechow, sloan and Sweeney (1991), Vafeas (2005), Uzun (2004) which studies the relationship between the board characteristics and earnings management. Once the size of the board is increasing, board consists of independent non executive directors with the sound financial expertise and meets very frequently, monitoring capacity of the board also increases and due to that opportunities available for the earnings management constrained. Further managers also reluctant engage in the earnings management since the possibilities of capturing by the board of directors are high with their expertise in the strong board. R square of the model tested is .72 . 
It indicates that board characteristics are strong and highly influencing to constrain the earnings management of the listed companies during the period of 2012-2015.

Table 02: Descriptive Statistics and Correlation Matrix

\begin{tabular}{|l|l|l|l|l|l|l|l|}
\hline Variables & Mean & Median & $\begin{array}{c}\text { Standard } \\
\text { Deviation }\end{array}$ & $\begin{array}{c}\text { Absolute } \\
\text { Residuals }\end{array}$ & BFEXP & BMEET & BCOMP \\
\hline BSIZE & 8.08 & 8 & 2.39 & .093 & $.045^{*}$ & -.057 & $.652^{*}$ \\
\hline BFEXP & 0.83 & 1 & .378 & .030 & & .341 & $.445^{*}$ \\
\hline BMEET & 5.95 & 5 & 2.97 & -.112 & & & $-.315^{*}$ \\
\hline BCOMP & 0.45 & 3 & .91 & -.012 & & & \\
\hline
\end{tabular}

* Correlation is significant at the 0.05 level (1-tailed)

\section{Table 03: Regression Results}

\begin{tabular}{|l|l|}
\hline \multicolumn{1}{|c|}{ Independent variables } & \multicolumn{1}{c|}{ Beta } \\
\hline BSIZE & $.048^{*}$ \\
\hline BFEXP & $-.037^{*}$ \\
\hline BMEET & $-.025^{*}$ \\
\hline BCOMP & $-.037^{*}$ \\
\hline R Square & 0.72 \\
\hline
\end{tabular}

* Significant at the 0.05 level

\section{Conclusion}

Based on the results of this study it can be concluded the board characteristics which is one of the key constitute in corporate governance are significant to constrain the earnings management of the listed firms in Sri Lanka. A firm with small board size, but with majority of the independent non executive directors and with sound financial expertise is capable of constraining the earnings management practices of the managers of the firms and enhances the financial reporting quality. Furthermore if firm can have more frequent board meetings it can constrain the earnings management practices of the managers also. Thus the relationship between the board characteristics to constrain the earnings management is significant and strong in Sri Lankan context. Once the firm is having a strong board with those characteristics it contributes to improve the financial reporting quality of the firms. 


\section{References}

Beasley, M. S. (1996). An empirical analysis of the relation between the board of director composition and financial statement fraud. The Accounting Review, 71(4), 433-465.

Carcello, J. V., \& Neal, T. L. (2002). Audit committee composition and auditor reporting. The Accounting Review, 75(4), 453-467. http://dx.doi.org/10.2308/accr.2000.75.4.453

Chang, J., \& Lian Sun, H. (2009). Crossed listed foreign firms earnings in formativeness, earnings management and disclosures of corporate governance information under SOX. The International Journal of Accounting, 44(1), 1-32. http://dx.doi.org/10.1016/j.intacc.2008.12.004

Dechow, P. M., Sloan, R. G., \& Sweeney, A. A. (1996). Causes and consequences of earnings manipulation: an analysis of firms subject to enforcement actions by SEC.

Contemporary Accounting Research, 13(1), 1-36. http://dx.doi.org/10.1111/j.1911-3846.1996.tb00489.x

Fama, E. F., \& Jensen, M. C. (1983). Agency problems and residual claims. Journal of Law and Economics, 26(2), 327-349. http://dx.doi.org/10.1086/467038

Healey, P. M., \& Wahlen, J. (2005). A review of the earnings management literature and its implications for standard setting. Accounting Horizons, 39(1), 163-197

Kothari, S. P., Leone, A. J., \& Wasley, C. E. (2005). Performance matched discretionary accrual measures. Journal of Accounting and Economics, 21(6), 163-197. http://dx.doi.org/10.1016/j.jacceco.2004.11.002

Kiel, G. C., \& Nicholson, G. J. (2002). Real world governance: Driving business success through effective corporate governance. Mount Eliza Business Review, 5(2), 17-24.

Peasnell, K., Pope, P., \& Young, S. (2000). Detecting earnings management using cross sectional abnormal accruals models. Accounting And Business research, 30(4), 313326. http://dx.doi.org/10.1080/00014788.2000.9728949

Uzun, H. (2004). Board composition and corporate fraud. Financial Analysist Journal, 60(4), 33-43. http://dx.doi.org/10.2469/faj.v60.n3.2619 